\title{
The Jewish Holocaust Centre, Melbourne: Public Pedagogies of Compassion and Connection
}

John G. Fox'

Victoria University

\begin{abstract}
There has been a long-sustained effort to understand the causes of the Holocaust (the attempted genocide of Jewish peoples in Europe in the middle of the twentieth century) and to prevent its repetition. The Jewish Holocaust Museum and Research Centre in Melbourne, Australia is a part of that endeavour through its museum, education program and support for research, and functions as a site of Public Pedagogy.
\end{abstract}

\section{Keywords}

holocaust studies, museums, public pedagogy

1 This article is based on a conference paper delivered at the Public Pedagogies Institute's 2016 conference with Dr Michael Cohen, Community Relations and Research Director of the JHC, and is submitted by the author with his approval and support.

Journal of Public Pedagogies, Number 2, 2017

Published by Public Pedagogies Institute: www.publicpedagogies.org

Open Access article distributed under a CC-BY-NC 4.0 license

URL http://jpp.vu.edu.au/

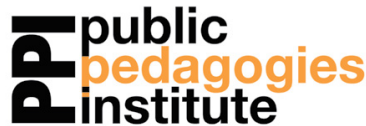


There has been a long-sustained effort to understand the causes of the Holocaust (the attempted genocide of Jewish peoples in Europe in the middle of the twentieth century) and to prevent its repetition. The Jewish Holocaust Museum and Research Centre in Melbourne, Australia (the 'JHC'), by means of its museum, education program and support for research, is a part of that endeavour. If 'public pedagogy...refers to the various forms, processes and sites of education and learning that occur beyond the realm of formal educational institutions' (Sandlin, Wright \& Clark 2011, p. 4), I suggest that the JHC is one of those sites.

The JHC is involved in the kinds of transformative learning that are central to public pedagogies (Burdick and Sandlin 2013, Ellsworth 2005, Giroux 2011, Sandlin et al 2011), particularly through the leading role of Holocaust survivors (and their recorded testimonies). This transformative potential is repeatedly demonstrated through one of the traditions maintained in the course I teach in (the social work course at Victoria University, Melbourne). Immediately following their last class, final year students gather with the staff to reflect on their four years with us. Moving around the room, each student is asked to share what stands out for them. Each year, almost without exception, they refer to their visit to the JHC and hearing the testimony of one of the survivors.

The transformative potential of the JHC's work is further demonstrated by reference to the recorded testimony of survivors. One, Fred Steiner (1998), had been imprisoned at the Auschwitz death camp. In his testimony he recounts how he was taken by one of the German officers to work at the officer's home, where Steiner met the officer's wife and children. Steiner shared the following reflection as part of his testimony:

'His wife was so nice to me. She...called me by my name, she offered me coffee. After that I've been thinking a lot about her...Did she know what went on 3 or 4 kilometres away? Did she ask the right questions? Did she get the right answers? I honestly want to believe that she did not know - that there were people who were good. It's much easier to live with yourself if you know these things...I honestly believe that she did not know, but that she did not ask the right questions because, after all, the flames [from the camp's crematoria] were visible from there as well'.

Elizabeth Ellsworth (2005, p. 32), in considering her encounter with the US Holocaust Memorial Museum, wrote of 'transitional spaces'. Sandlin and Milam (2008, p. 339) describe those spaces as 'hinges [that] create possibilities for both inside and outside - self and society - to be disrupted and reconfigured'. I suggest that encounters with the JHC provide similar promising moments for change.

This transformative potential is one of the reasons why the JHC may be seen to be engaged in public pedagogy. Another reason is the influence of neoliberalism and its promotion of an exaggerated, self-interested individualism and the loss of public space, which features prominently in the literature (Burdick and Sandlin 2013, Charman and Ryan 2015, Robbins 2009, Sandlin and Milam 2008). So damaging has been neoliberalism's influence, that Henry Giroux (2004, p. 15; 2011, p. 7), has linked it to what he calls 'proto-fascism' or, borrowing from Betram Gross, 'fascism with a friendly face'. One of the key lessons learned by the Jewish community in the Holocaust is just how fragile a democracy can be. In these times we may find we need their witness even more than before.

Lastly, I believe that the work of the Centre, particularly the survivors, evidences the importance of our bodies, and bodily reactions, in transformational learning. These three elements have also led me to draw on the work of the German Jewish social theorist, Theodor Adorno, who considered the elements of Western culture that facilitated the Holocaust and the means by which we might best prevent its repetition. This concern occupied 
much of Adorno's life, especially after he returned to post-war Germany, and I believe his work then in relation to public education - to cultural transformation - makes his work very relevant today.

\section{The Jewish Holocaust Museum and Research Centre}

The JHC is part of a long-sustained global endeavour to understand the causes of the Holocaust and prevent its repetition. To understand its contributions to public pedagogy it is necessary to briefly review the key events of the Holocaust.

The National Socialist German Workers Party (the 'Nazis') assumed power in Germany in 1933 and opened their first concentration camps shortly thereafter (Friedlander 1997). The short-lived democracy of the Weimar Republic ended that year with the fabrication of a supposed national emergency. The Nazi persecution of Jewish peoples escalated from that time onwards. The infamous Nuremberg laws of 1935 excluded Jewish peoples from citizenship and from much of the social and economic life of the nation (Friedlander 1997). The outbreak of war in 1939 freed the Nazis from restraint and saw them experiment with militarised forms of mass murder-mass shootings-and ultimately move to the industrialised mass murder in the death camps of Chelmno, Belzec, Sobibor, Treblinka, Majdanek and Auschwitz-Birkenau (Friedlander 2007). By the end of the war in 1945, over 6,000,000 Jewish people had been killed (Friedlander 2007).

Following the war, large numbers of survivors sought to travel far from Europe, and a significant proportion of them came to Melbourne (Paratz and Katz 2011). Understandably, many could not speak of their experience for a long time. However, following the development of a 'Holocaust denial' movement late last century, many survivors felt obliged to speak out, and the JHC emerged out of that engagement in 1984. Their commitment to give witness to the Holocaust is powerfully expressed, both in words and image, by the banner hanging outside the JHC's premises, which features the tattooed arm of a survivor and the words 'history you can't erase' (see figure 1).



Figure 1: History You Can't Erase

The JHC aims to 'combat antisemitism, racism and prejudice in the community and foster understanding between people' (JHC 2016a). While Jewish peoples suffered in greater numbers than others under the Nazis, they also give witness to others who were systematically persecuted-people with a disability, the Roma and Sinta ('gypsies'), homosexuals, 'asocials' such as sex workers and the long-term unemployed, so-called habitual criminals, 
and Jehovah's Witnesses. The JHC is also mindful of parallel events in other communities, and works with them, including the Australian Indigenous community and survivors of the Rwandan and Cambodian genocides.

The JHC pursues its aims through a variety of means. One is physical-the building and the artefacts and artworks it contains-and begins with the public face of the museum: Andrew Rogers' sculptured columns, the Pillars of Witness. These comprise 76 panels, each displaying images of the Holocaust, which form the exterior fencing and gateway to the museum. Photographs of some of the panels are set out as figures 2-6 below.
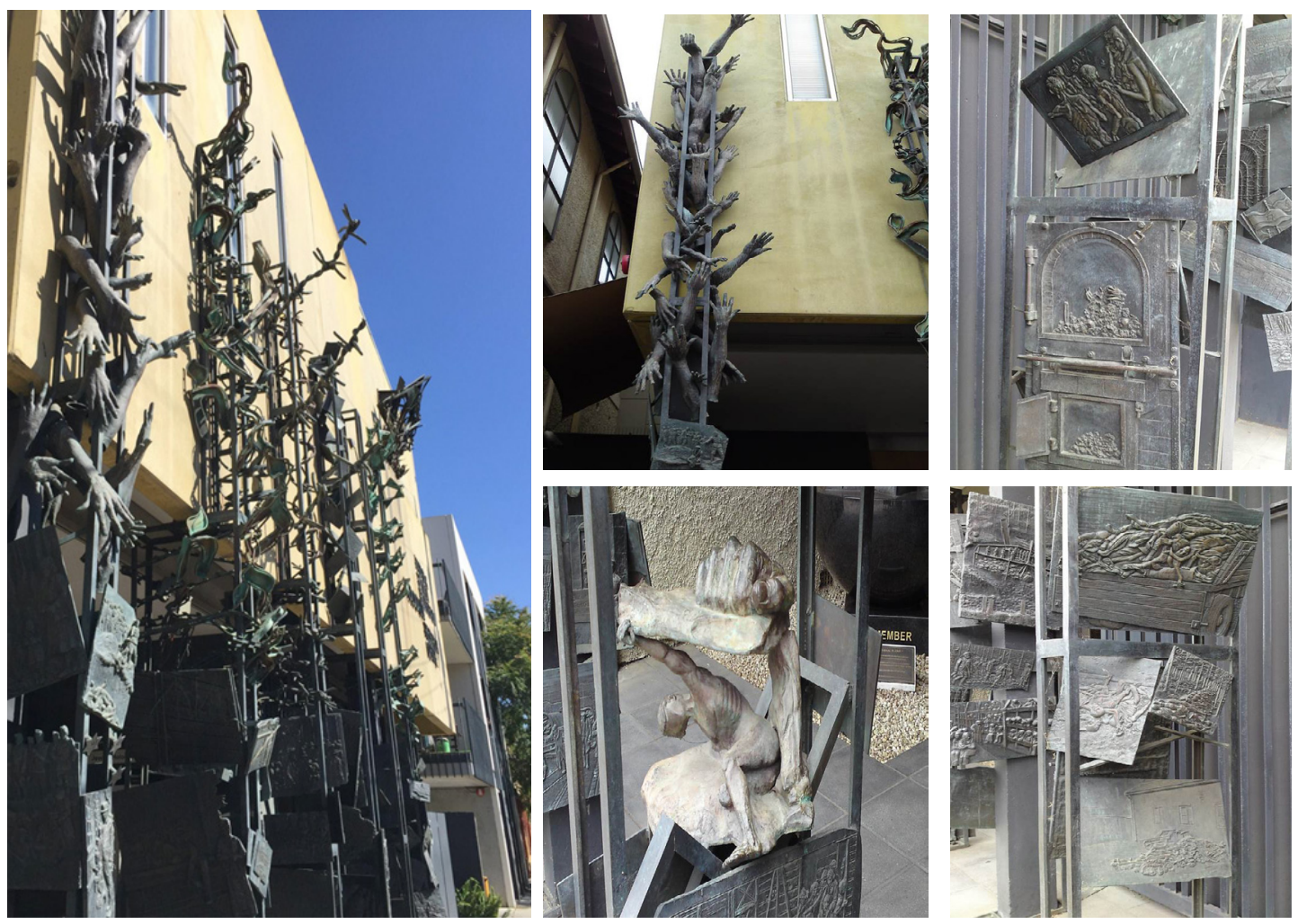

Figures 2-6: Pillars of Witness

The JHC's museum also houses many artefacts, most of which were contributed by local survivors and their families. Many people visiting the JHC are familiar with Oscar Schindler, and the many people he saved, especially given Stephen Spielberg's film Schindler's List. Recently, the family of a local survivor discovered the casting mould for the ring that was given to Schindler and that mould (figure 7 below) now forms part of the JHC's permanent exhibit.

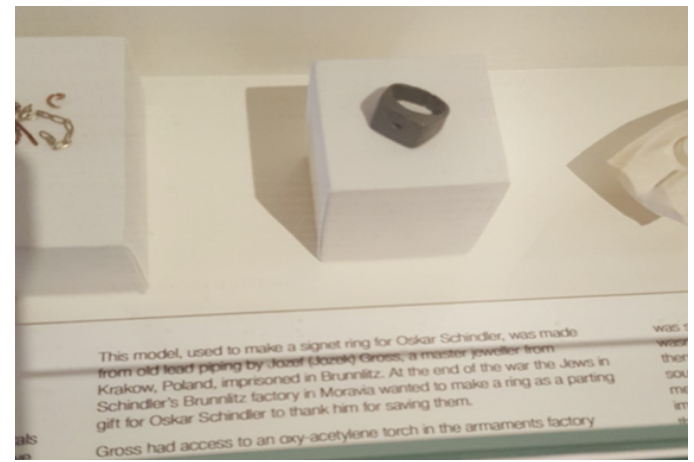

Figure 7: Schindler's Ring Mould 
The physical dimension of the centre's work also extends to a range of artworks. Some of these, such as that in figure 8 , were contributed by survivors. Others reflect the broader community's engagement with the JHC. One of these-a clear plastic tube containing small buttons representing the 1,500,000 children killed in the Holocaust (figure 9 below) -speaks powerfully of the community's involvement in the JHC's works.
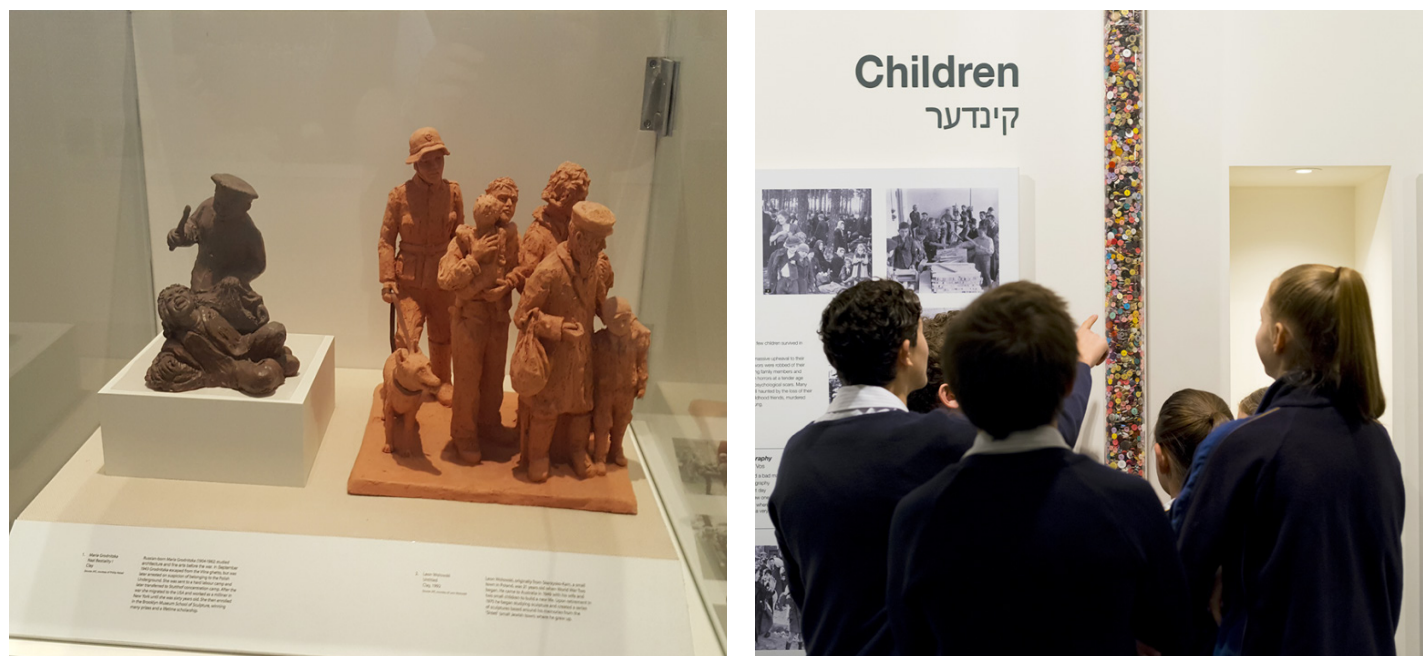

Figure 8: Sculptures contributed by survivors. Figure 9: Buttons Tube

The tube was initially constructed by students at Bialik College, Melbourne, in 2007, and donated to the JHC. The students believed that buttons, like children, come in many different shapes, sizes and colours and would therefore constitute a fitting memorial.

The 'button project' is significant for two reasons: first, because it indicates just how 'public' or communal the work of the JHC is; and, secondly, because the JHC's education programmes are central to its work. The JHC (2016a) regards 'the finest memorial to all victims of racist policies to be an educational program'. Almost 21,000 primary, secondary and tertiary students participated in those programs in 2015 (Fineberg 2016).

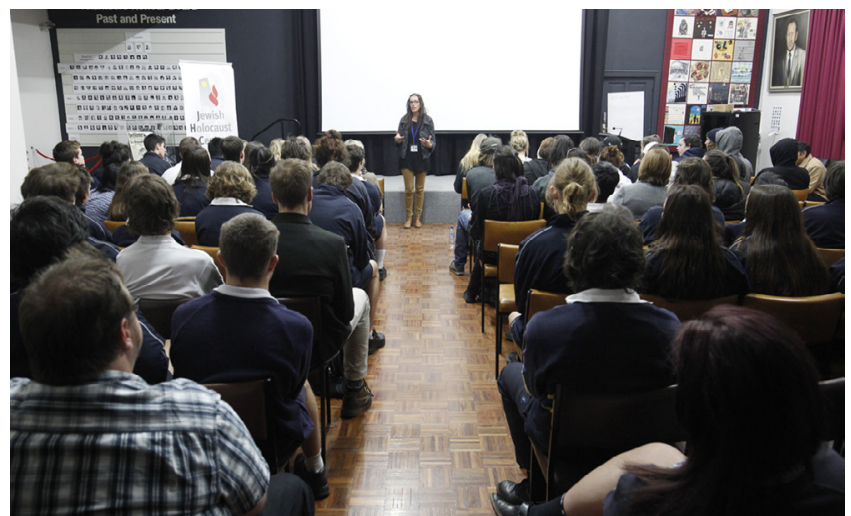

Figure 10: Staff Presentation

While the JHC often tailors its programs to meet the needs of the relevant school or university, its program usually comprises three elements. They begin with a presentation on the Holocaust by one of the staff, which includes film taken by a young US soldier participating in the liberation of the Dachau concentration camp (see figure 10). It captures his own shocked reactions and ends with him asking how could one human being do this to another human being?' Students are then prompted to answer that question themselves and to discuss the circumstances that enabled the Holocaust to occur. 


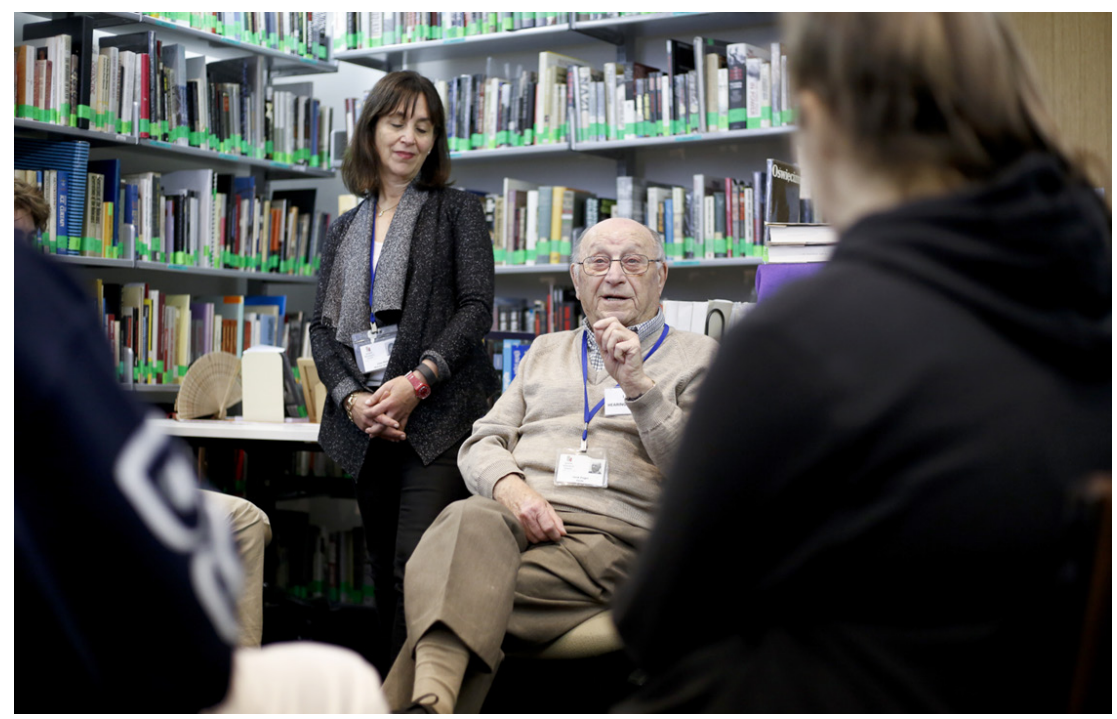

Figure 11: Survivor Presentation

After this, they meet with one of the survivors, who share their own first-hand experience of the Holocaust, and their reflections on it (see figure 11).

Here, again, students are invited to ask questions and make their own connections to the survivors' testimony. They conclude their visit by walking through the permanent exhibition (see figures 12 and 13), where they are guided in small groups by the JHC's volunteers, who are often children of survivors themselves, share their own insights and reflections with students, and further demonstrate the communal or public character of the JHC's educational endeavours.
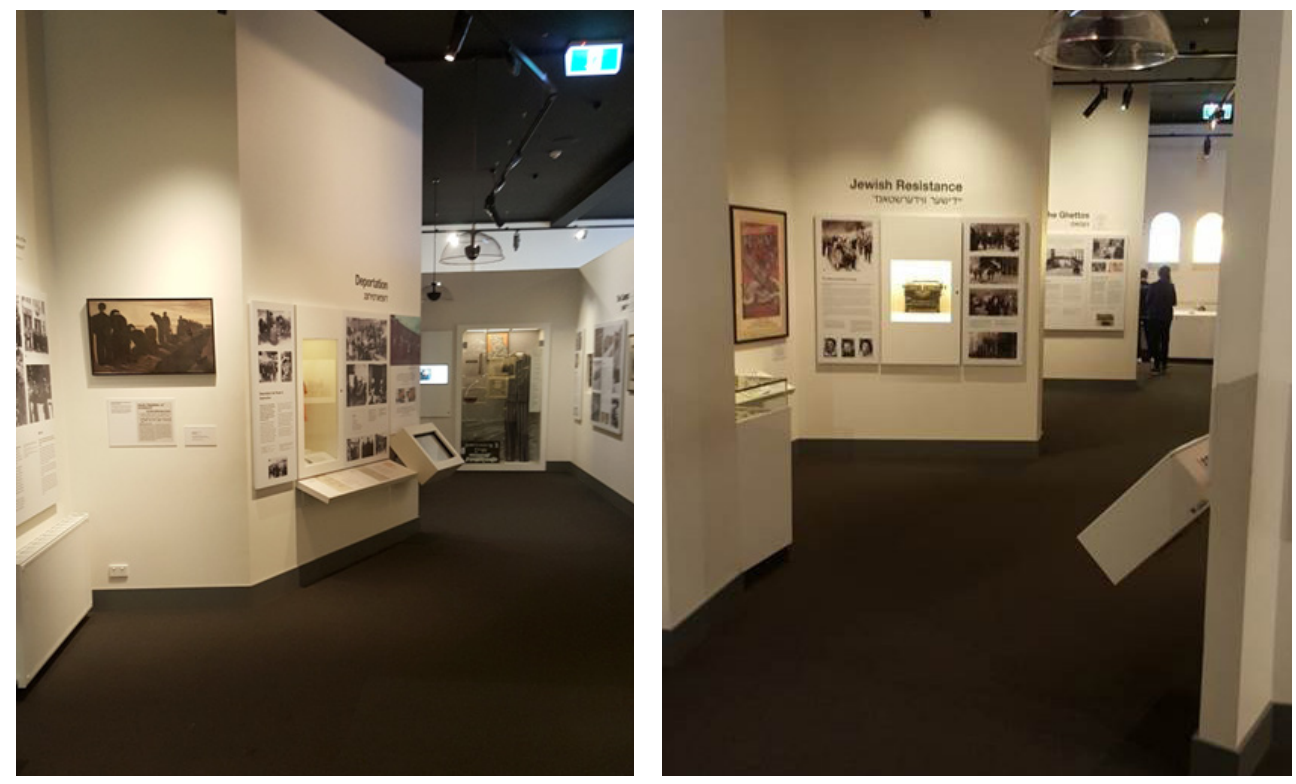

Figures 12 and 13: Main Exhibit

\section{Compassion, Connection and Transformative Learning}

There is much more that could be said about the Centre and its activities, but in this article I want to focus on one aspect-the interaction with the survivors, some of whom are pictured in figures 14-16 below. 

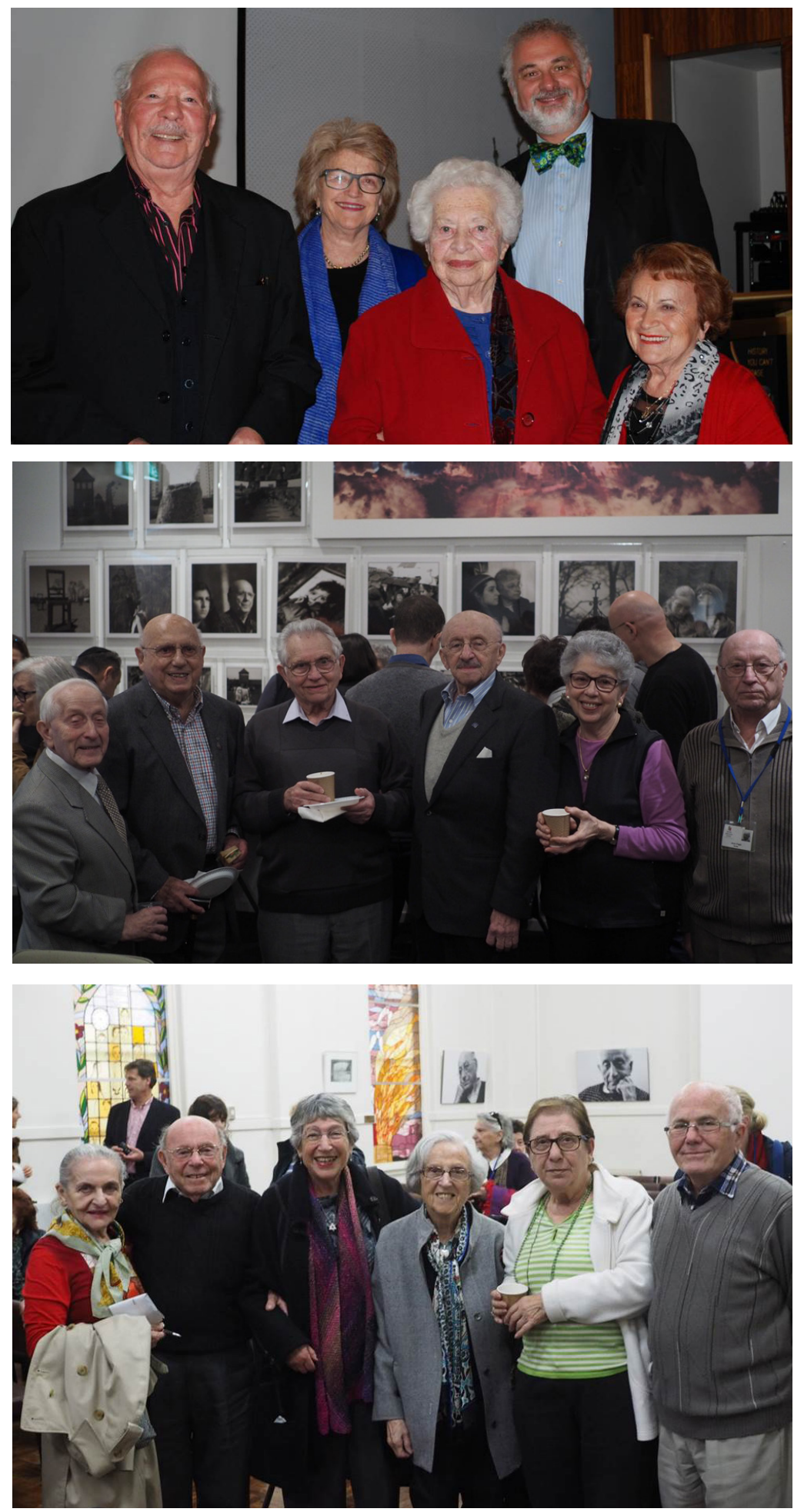

Figures 14-16: Survivors

The survivors' contributions, and their impact on others, exemplifies the 'sensational pedagogies' (Burdick and Sandlin 2013, Ellsworth 2005, Springgay 2011) that are of central interest to public pedagogies today. As Springgay (2011, p. 651) has put it, these 'pedagogies...recognise the importance of corporeality, emplacement, and sensation in learning. I've been taking my students to hear survivors' testimonies for some years now, and the survivors make an impact, every time, on both the students and me. They provide a living, 
embodied connection to an almost-unimaginable past: more importantly, they remember or re-enact it before us as they recall their experience and reflect upon it. Their testimony is powerful for many of the things explored in public pedagogies. It is a performance, embodied, sensual, and invokes, if not directly expresses, extraordinary suffering and loss. This power connects to the work of Theodor Adorno, who was profoundly affected by what he learned about the Holocaust. He (1973, p. 365) held that 'the [concentration] camps, without any consolation, burned every soothing feature out of the mind, and out of culture': so much so that he argued that 'Hitler had given us a new categorical imperative'-that is a new, universally-binding, foundation for morality. For Adorno, the 'unvarnished materialist motive'-the influence of our bodies and the material world-provided that alternative foundation.

The culture that had 'burned' in the camps was that which treated human activities as distinct from nature: above all, as products of reason. It was the culture expressed in the treatment of reason as something that could, and should, be understood and applied free of all other influences-the culture that treated this independent reason as the foundation of morality. This culture treated the best of our humanity as located in our minds and dependent upon the discipline and repression of all else, including our bodies and that 'gut reaction'-that empathic response-we call compassion. It depended upon what Adorno $(2005$, p. 271, 274) called 'coldness'. For Adorno, this long-practised, consistently-celebrated, repression enabled otherwise 'good' people, to draw on Fred Steiner's (1998) words, to avoid asking 'the right questions' and seeking 'the right answers'. At the very least it facilitated the Holocaust. It did so because the public pedagogies of the West those everyday aspects of 'popular culture and informal cultural institutions [that shape] the master narratives of adult identity' (Sandlin et al 2011, p. 7)-taught that mind should dominate matter, and 'cold' reason, emotion.

Contrary to this tradition, Adorno located the best of our humanity in our bodily reactions. He (1973, p. 228-9) called this an 'impulse', and this term, together with Adorno's prominent drawing on aesthetic theory, has attracted a lot of attention (see, eg, Bowie 2013, Foster 2007, and Schweppenhauser 2009). However, this attention has neglected his particular choice of words in referring to the 'unvarnished materialist motive' when discussing the new foundation for morality. Here I believe Adorno was drawing on the materialist tradition, spanning from Epicurus to Marx, which placed limited confidence in discursive reasoning or rationality to transform deeply held beliefs. Instead, the materialist tradition looked to bodily experience-the capacity of suffering to force a confrontation with, and potentially the transformation of, such beliefs (Fox 2015).

Adorno took this thinking one step further. Rather than rely on the direct experience of suffering, he emphasised the potential of witnessing suffering. For Adorno, the witnessing of pain is not merely engaging with an 'external' or separate event. He argued that to witness another suffering was deeply 'internal'-it affected our sense of self-and it is here I think his works engage with some of the central concerns of contemporary debates in public pedagogies. He saw this kind of experience as providing a 'shock' or 'shudder' that prompted 'an involuntary adjustment' (Adorno 2006, p. 213). For Adorno, it triggered a response because he saw the foundation of our engagement with the world as mimesiscopying, not in a controlled manner, but as an 'involuntary' echo, shudder, or shiver. This too reflects the materialist tradition, which treats matter as active and volatile, and hence the body as difficult and unruly, demanding and disrupting its discipline, and our conceptions. This is what Feuerbach (1972, p. 144), one of Marx's key influences, and they both were key influences on Adorno, described as the 'original antithesis'-not original 
in a chronological sense but more an ontological one: that the ground of our being, and our sense of self, is founded in the interaction between the 'external' material world and our own materiality-our bodies. This relationship, as much feminist and postmodern thought has emphasised, is a site of daily struggle (see, for example, Bordo 2003, Foucault 1990a and 1990b). Adorno (1997, p. 331) described this tense interaction as triggering 'that shudder in which subjectivity stirs without yet being subjectivity'. He saw our involuntary empathy with others' suffering as prompting an encounter or recollection with the 'original antithesis', the site at which we construct our sense of self-and hence a reminder of our deep interconnection with the 'external' world. We think this is just the potential of public pedagogies explored by people like Ellsworth (2005) and Sandlin (Sandlin \& Milam 2008)-moments in which we can discover our self is not set in concrete and is certainly not separate, but always a 'work in progress' or in transition; moments in which we could move our selves, or, perhaps more accurately, find ourselves moved, in other directions; moved, perhaps by compassion, to rediscover the connections to others obscured by 'cold' reason.

\section{Conclusion}

To draw on the theme of the Public Pedagogies Institute's 2016 conference, the JHC is a dynamic location for learning and teaching that is 'back to front'. As a museum, it is not a 'traditional' learning institution. As a community endeavour, its learning activities are not led by 'credentialed' teachers, but by members of the community and, in particular, local Holocaust survivors. Unlike more conventional approaches, it privileges sensual or bodily learning over language-based, cognitive learning.

The JHC reflects the vitality, importance and difficulties of public pedagogy, especially in contesting the processes of dissociation and disinterest promoted by powerful contemporary discourses, such as neoliberalism and racism. It developed in response to those threats in the hope to prevent their repetition. Today, if Henry Giroux (2004, 2011a, $2011 \mathrm{~b}, 2015)$ is correct, and the US and others practicing neo-liberal politics are becoming increasingly authoritarian, the need for this work may be even greater yet.

It is important to remember the responses of so many Jewish people in the lead up to the Holocaust, who found anything like it unimaginable in so civilised a place as Germany. It is important to remember how surrendering some features of democracy can be the first steps onto a slippery slope. And, if Adorno is correct, we cannot see ourselves as living at some safe distance from that slope-if the devaluation of the body involves the repression of compassion, the coldness that facilitated the Holocaust remains a risk within our culture today. The evidence of that risk is evident in Australia's recent treatment of asylum seekers. Moshe Fiszman (see figure 17), another survivor whose testimony is preserved by the JHC, emphasised this risk.

He urged people in a country like Australia to not be complacent:

'because they are born here, and they've got all the rights in this country under the constitution...We also had rights. We also had a constitution. We were also free people... That country [Germany], that intelligent nation, which gave the world the biggest philosophers. They gave us Beethoven and Mozart and Schubert and Schumann. We had Heine and Nietzsche. We had Karl Marx and Rosa Luxemburg and we had Adolf Hitler, and have had all these people who were prepared and ready in the name of their culture to murder innocent people' (Fiszman, 1993). 


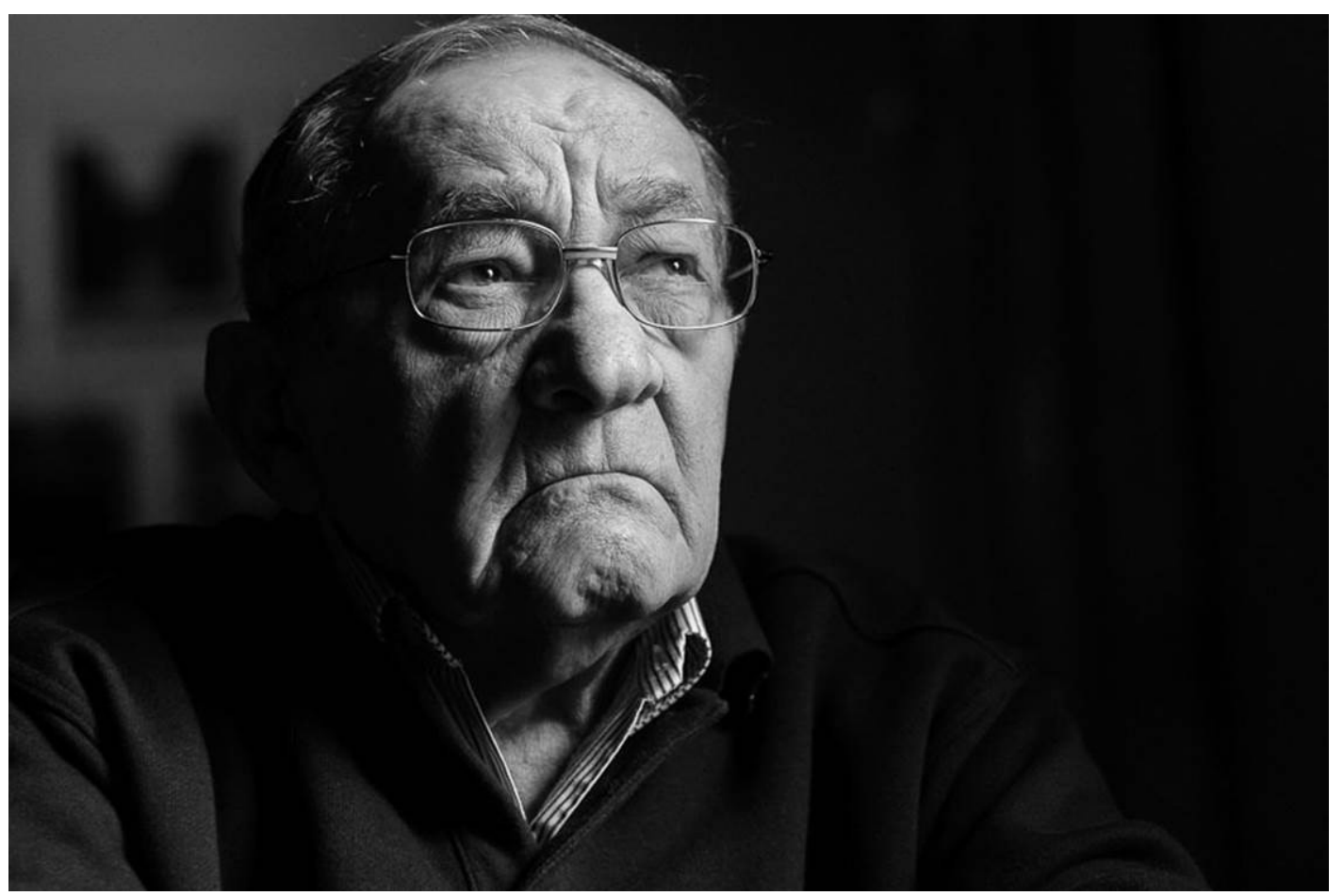

Figure 17: Moshe Fiszman

This is not learning turned 'back-to-front', in the sense of being out of place. It is learning being located in its true place - as part of the public domain, as part of culture and politics, as part of safeguarding and promoting the best of our humanity. It is public pedagogy.

\section{References}

Adorno, T W 1973, Negative Dialectics, Routledge, London.

Adorno, T W 1997, Aesthetic Theory, University of Minnesota Press, Minneapolis.

Adorno, TW 2005, Critical Models: Interventions and Catchwords, Columbia University Press, New York.

Adorno, T W, 2006, History and Freedom, Polity, Malden.

Bordo, S 2003, Unbearable Weight: Feminism, Western Culture, and the Body, University of California Press, Berkeley, USA.

Bowie A 2013, Adorno and the Ends of Philosophy, Polity, Cambridge.

Burdick J and Sandlin JA 2013, 'Learning, Becoming and the Unknowable: Conceptualisations, Mechanisms, and Process in Public Pedagogy Literature', Curriculum Inquiry, Vol. 43, Iss. 1, pp 142-177.

Cregan, K 2006, The Sociology of the Body, Sage, London, UK.

Ellsworth, E 2005, Places of Learning: Media, Architecture, Pedagogy, Routledge, New York.

Feuerbach, L 1972, 'On "The Beginning of Philosophy”' in Hanfi, Z (Ed.), The Fiery Brook: Selected Writings of Ludwig Feuerbach, Anchor Books, New York. 
Fineberg, W 2016, The Voice, vol.7, iss. 2, p 1.

Fiszman, M 1993, Survivor Testimony 0441B, video recording, Jewish Holocaust Centre, Melbourne.

Foster, R 2007, Adorno: the Recovery of Experience, State University of New York Press, Albany.

Foucault, M 1990a, The History of Sexuality: An Introduction, Volume 1, Vintage Books, New York, USA.

Foucault, M 1990b, The History of Sexuality: the Use of Pleasure, Volume 2, Vintage Books, New York.

Fox, JG 2015, Marx, the Body, and Human Nature, Palgrave Macmillan, London.

Friedlander, S 1997, Nazi Germany and the Jews: Volume 1-The years of persecution 19331939, Harper Perennial, New York.

Friedlander, S 2007, The Years of Extermination: Nazi Germany and the Jews 1939-1945, Harper Perennial, New York.

Giroux, HA 2004, The Terror of Neoliberalism: Authoritarianism and the Eclipse of Democracy, Paradigm Publishers, Boulder.

Giroux, HA 2011a, On Critical Pedagogy, Bloomsbury, New York.

Giroux, HA 2011b, Zombie Politics and Culture in the Age of Casino Capitalism, Peter Lang, New York.

Giroux, HA 2015, Dangerous Thinking in the Age of the New Authoritarianism, Routledge, Oxford.

Jewish Holocaust Centre 2016a, www.jhc.org.au, 'Mission', Available HTTP: http:// www.jhc org.au/about-the-centre.html> (accessed 10 October 2016).

Paratz, ED and Katz, B 2011, 'Ageing Holocaust Survivors in Australia', The Medical Journal of Australia, vol. 194, iss. 4, pp 194-7.

Robbins, CG 2009, 'Searching for Politics with Henry Girioux: through Cultural Studies to Public Pedagogy and the "Terror of Neoliberalism", Review of Education, Pedagogy, and Cultural Studies, Vol. 35, Iss. 5, pp 428-478.

Sandlin JA and Milam JL, 2008, “Mixing Pop (Culture) and Politics”: Cultural Resistance, Culture Jamming, and Anti-Consumption Activism as Critical Public Pedagogy', Curriculum Inquiry, Vol. 38, Iss. 3, pp 323-350.

Sandlin JA, Wright, RR and Clark C 2011, 'Reexamining Theories of Adult Learning and Adult Development through the Lenses of Public Pedagogy', Adult Education Quarterly, Vol. 63, Iss. 1, pp 3-23.

Springgay, S 2011, "The Chinatown Foray" as sensational pedagogy', Curriculum Inquiry, Vol. 41, Iss. 5, pp 636-656.

Steiner, A 1998, Survivor Testimony 0982B, video recording, Jewish Holocaust Centre, Melbourne.

Schweppenhauser, G 2009, Theodor W. Adorno: An Introduction, Duke University Press, Durham. 